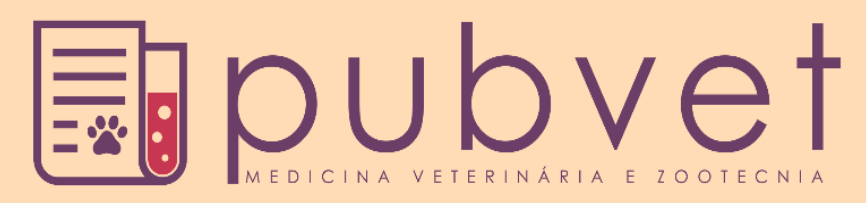

https://doi.org/10.31533/pubvet.v15n06a826.1-8

\title{
Morphoquantitative evaluation of the heart of equine athletes
}

\author{
Vinicius José Lopes ${ }^{1}$, Guilherme Barbosa da $\operatorname{Costa}^{2^{*}} \bullet$, Amanda Garcia Pereira ${ }^{3}$, Lucas de \\ Freitas Pereira $^{4}{ }^{\bullet}$, Larissa Fernandes Magalhães ${ }^{4}{ }^{\bullet}$, Daniel dos Santos ${ }^{5}$, Daniel Paulino \\ Junior ${ }^{6}$
}

\author{
${ }^{\text {I} P r o g r a m a ~ d e ~ A p r i m o r a m e n t o ~ e m ~ E q u i n o, ~ H o s p i t a l ~ V e t e r i n a ́ r i a ~ C r i s p i m ~ e ~ S t e v a n a t o, ~ S a ̃ o ~ J o s e ́ ~ d o ~ R i o ~ P r e t o, ~ S P, ~ B r a s i l ~}$ \\ ${ }^{2}$ Médico Veterinário na Empresa JA Saúde Animal \\ ${ }^{3}$ Doutoranda em Patologia de Animais Silvestres da Universidade Estadual de São Paulo UNESP - Campus Jaboticabal \\ ${ }^{4}$ Docente Curso de Medicina Veterinária, Universidade de Franca, Franca, SP, Brasil \\ ${ }^{5}$ Programa de Pós-Graduação em Ciência Animal, Universidade de Franca, Franca, SP, Brasil \\ ${ }^{6}$ Programa de Pós-Graduação em Promoção da Saúde, Universidade de Franca, Franca, SP, Brasil \\ *Autor para correspondência, e-mail: guibc14@hotmail.com
}

\begin{abstract}
The present work has as main objective to analyze the equine cardiac ventricles after death, from the morphoquantitative measurement. Six hearts of different races of horses with the presence or absence of different sports skills were used. The hearts were collected after the animal died and the cause of death was not stated. Six hearts of the equine species were analyzed, being 50\% males and 50\% females. As for the breed $33.3 \%$ was Quarter mile, 33.3\% was Machador Broad Sleeve and $16.6 \%$ was Paulista Broad Sleeve and $16.6 \%$ was PSI. About athletic life, $50 \%$ were considered equine and the average weight of the animals was $426.83 \mathrm{~kg}$, with the lowest weight $295 \mathrm{~kg}$ and the highest $560.0 \mathrm{~kg}$. Regarding the dimensions of the hearts analyzed, the average weight of the ventricles was $2.71 \mathrm{~kg}$, with the lowest weight $1.63 \mathrm{~kg}$ and the highest weight $3.83 \mathrm{~kg}$; On the size of the base, it found an average of $22.28 \mathrm{~cm}$, with the base smaller $17.0 \mathrm{~cm}$ and the largest base 25; As for the axis, the average was $25.66 \mathrm{~cm}$, being the smallest of $22.0 \mathrm{~cm}$ and the largest of 30. Regarding the number of slices, case 1 was the smallest, being 9 and Case 2 and 5 presented a larger number of slices, being 12. Physical activity in horses seems to be associated with myocardial hypertrophy and this fact may increase the axis and allow greater cuts and action analysis.
\end{abstract}

Key words: Format, horse, myocardium, size

\section{Avaliação morfoquantitativa do coração de equinos atletas}

Resumo. O presente trabalho possui como objetivo analisar os ventrículos cardíacos da espécie equina após o óbito, a partir da mensuração morfoquantitativa. Foram utilizados seis corações de diferentes raças de equinos com ou sem aptidões esportivas distintas. Os corações foram coletados imediatamente após o óbito do animal e a causa morte não foi declarada. Foram analisados seis corações, sendo 50\% machos e 50\% fêmeas. Quanto à raça 33,3\% eram Quarto de Milha, 33,3\% eram Manga Larga Machador, 16,6\% era Manga Larga Paulista e 16,6\% eram da raça PSI. Sobre a vida atlética, 50\% eram considerados equinos atletas e o peso médio dos animais foi de $426,83 \mathrm{Kg}$, sendo o menor peso $295 \mathrm{Kg}$ e o maior $560,0 \mathrm{Kg}$. Sobre as dimensões dos corações analisados, o peso médio dos ventrículos foi $2,71 \mathrm{Kg}$, sendo o menor peso $1,63 \mathrm{Kg}$ e maior peso $3,83 \mathrm{Kg}$; sobre o tamanho da base, encontrou-se a média de $22,28 \mathrm{~cm}$, sendo a menor base $17,0 \mathrm{~cm}$ e maior base 25; quanto ao eixo, a média encontrada foi $25,66 \mathrm{~cm}$, sendo o menor eixo de $22,0 \mathrm{~cm}$ e o maior foi 30. Em relação a quantidade de fatias, a amostra 1 foi o que apresentou menor quantidade, sendo 9 e a amostra 2 e 5 apresentaram maior quantidade de fatias sendo 12 . 
A prática da atividade física em cavalos parece estar associada com a hipertrofia do miocárdio, esse fato pode aumentar o eixo e permitiu maiores cortes e analises das estruturas.

Palavras-chave: Cavalo, formato, miocárdio, tamanho

\section{Evaluación morfocuantitativa del corazón de equinos atletas}

Resumen. El presente estudio tiene como objetivo analizar los ventrículos cardíacos de la especie equina después de la muerte, a partir de la medición morfo-cuantitativa. Se utilizaron seis corazones de diferentes razas de caballos con o sin diferentes habilidades deportivas. Los corazones se recolectaron inmediatamente después de la muerte del animal y no se declaró la causa de la muerte. Se analizaron seis corazones, 50\% masculinos y 50\% femeninos. En cuanto a la carrera, el 33,3\% fueron Quarter Mile, el 33,3\% Manga Larga Machador, el 16,6\% Manga Larga Paulista y el 16,6\% PSI. En cuanto a la vida atlética, el $50 \%$ fueron considerados atletas equinos y el peso promedio de los animales fue de 426,83 $\mathrm{kg}$, siendo el peso menor $295 \mathrm{~kg}$ y el mayor $560,0 \mathrm{~kg}$. Sobre las dimensiones de los corazones analizados, el peso medio de los ventrículos fue de $2,71 \mathrm{~kg}$, siendo el peso más bajo $1,63 \mathrm{~kg}$ y el peso más alto $3,83 \mathrm{~kg}$; en el tamaño de la base se encontró un promedio de $22.28 \mathrm{~cm}$, siendo la base más pequeña $17,0 \mathrm{~cm}$ y la base más grande 25; En cuanto al eje, la media encontrada fue de $25,66 \mathrm{~cm}$, siendo el eje menor $22,0 \mathrm{~cm}$ y el mayor 30 . En cuanto al número de cortes, la muestra 1 fue la que presentó menor cantidad, siendo 9 y las muestras 2 y 5 presentaron mayor número de cortes, siendo 12. La práctica de actividad física en caballos parece estar asociada a la hipertrofia miocárdica, hecho que puede aumentar el eje y permitió mayores cortes y análisis de las estructuras.

Palabras clave: Caballo, forma, miocardio, tamaño

\section{Introduction}

The introduction of the equine species in sport took place in Ancient Greece, starting from the Olympic Games, which competed in saddle or hitch races (Ferreira et al., 1996; Santos, 2015). According to the Study of the Horse Agribusiness Complex, Brazilian equinoculture moved 16.5 billion reais in 2015 (Lima \& Cintra, 2016).

High level competitions require horses to have high physical training acquired with adequate training, so that there is less risk of injury (Hinchcliff et al., 2008; Mirian, 2008). Corresponding to this condition, horses can develop ventricular hypertrophy and other cardiac changes, due to exhausting high-intensity training (Hinchcliff et al., 2008; Young et al., 2005). The heart is responsible for providing and maintaining systemic circulation, according to the body's metabolic requirements, through blood pumping (Dyce et al., 2004; Marr \& Bowen, 2011). Internally, the atria have thinner muscle layers, while in the ventricles the walls are thicker making up most of the heart. reflux (Cunningham, 2011; Dyce et al., 2004).

According to the study by Leite et al. (2004) in English Thoroughbred horses (PSI), the myocardial fibers are covered by a complex network of connective fibers, which act as interconnector tissue, composed of collagen, myocytes and capillary blood vessels.

The decrease in performance of horses is related to several organic disorders, the main causes of which are related to the systems: musculoskeletal, respiratory and cardiovascular (Martin Júnior et al., 2000; Yonezawa et al., 2009). To meet cardiovascular demand, the organ responds to increased activities by promoting biochemical, electrical, morphological and mechanical changes in the myocardium. And, thus, it prevents the progression of lesions in the ventricular walls (Dumont et al., 2010; Pluim et al., 2000). Horses have less connective fibers around their individual cardiac muscle fibers. The latter, in general, are increased in size, in order to support the heart in the face of all the effort required (Leite et al., 2004).

The present study has as main objective to analyze the cardiac ventricles of the equine species after death, from the morpho-quantitative measurement, seeking new discoveries for veterinary cardiology and equine sports medicine. 


\section{Material and methods}

This study was carried out at the Veterinary Hospital of the University of Franca (UNIFRAN), six hearts of different breeds of horses were used with the presence or absence of different sports skills.

The hearts were collected immediately after the animal's death and the cause of death was not declared. All hearts of animals of the equine species were included from June 2018 to July 2019.

To carry out this study, the following steps were necessary: I) Study of the cardiovascular system; II) Literature review and II) Study on the methods of obtaining ventricular measurements.

In the autopsy room, the atria were discarded and removed with the aid of surgical scissors (metzembaum) and the ventricles were morphometrically analyzed (Figure 1) in the following order: the hearts were washed so that the excess would not interfere with the weighing.

Weighing was done on a digital scale; The measurement of the axis (measure from the apex to the base) was carried out with an aluminum ruler compatible with the caliper, as well as the width of the base, then cross-sections were made approximately every two centimeters (Figure 2: B and C) to the left and right ventricular chamber, the ventricular septum and the right and left walls were measured using a caliper (Figure 2: D, E, F, G and H).

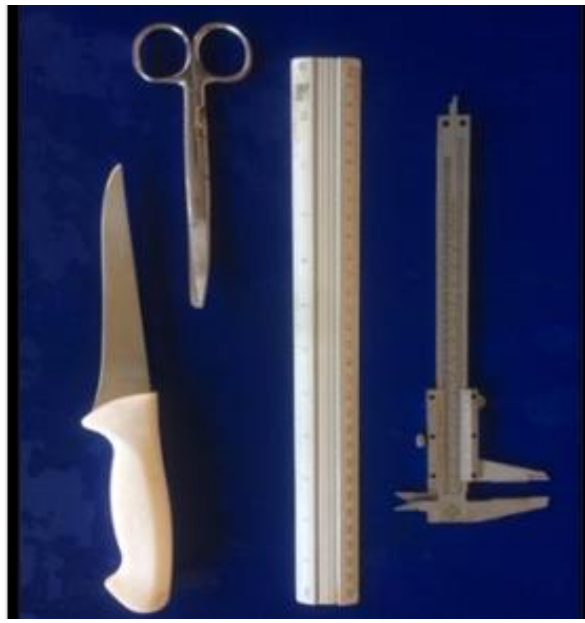

Figure 1. Materials used to perform the morpho-quantitative analysis of the horse's heart.

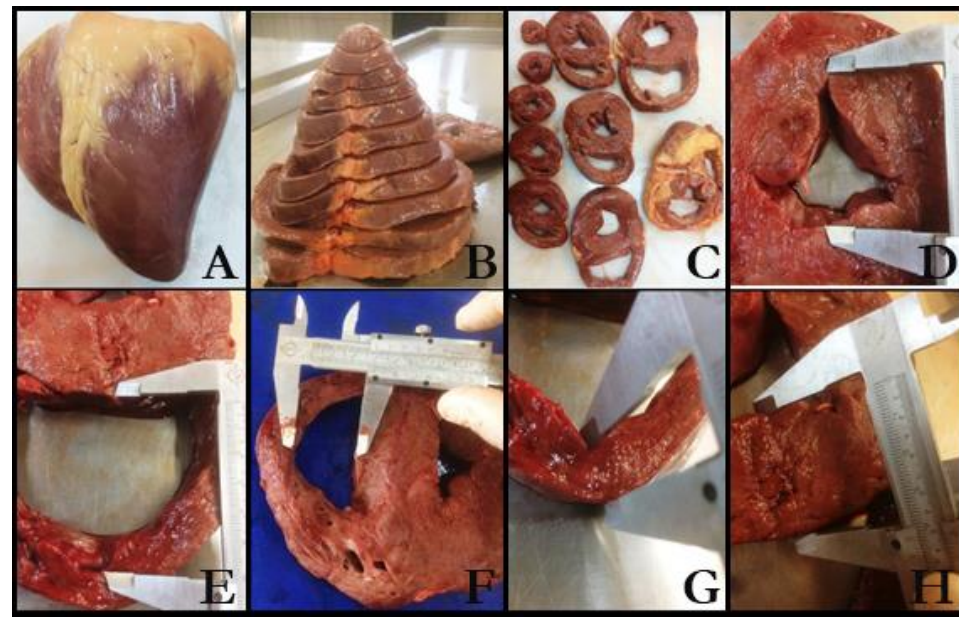

Figure 2. Synthesis of the stages of preparation of the equine heart, right and left walls using a caliper $\mathbf{A}$ : Whole heart of an equine in the left view, $\mathbf{B}$ : Equine heart, transversal cuts every two centimeters, $\mathbf{C}$ : Arrangement of the layers of the equine heart, $\mathbf{D}, \mathbf{E}$ and $\mathbf{F}$ : Measurements of the internal lumen of the left ventricle with a caliper, $\mathbf{G}$ and $\mathbf{H}$ : Measurement of the left ventricle wall with a caliper.

To perform the analysis of the results, a spreadsheet was created in excel and the analyzes were performed using a descriptive technique (mean and percentage), and to calculate the volume of the left ventricular chamber, an estimate was made using the cylinder volume calculation for each slice, after the analysis of each slice, they were added to determine the ventricular volume, that is, $\mathrm{V}=\pi \cdot \mathrm{r}^{\wedge} 2 . \mathrm{h}$ (Figure 3).

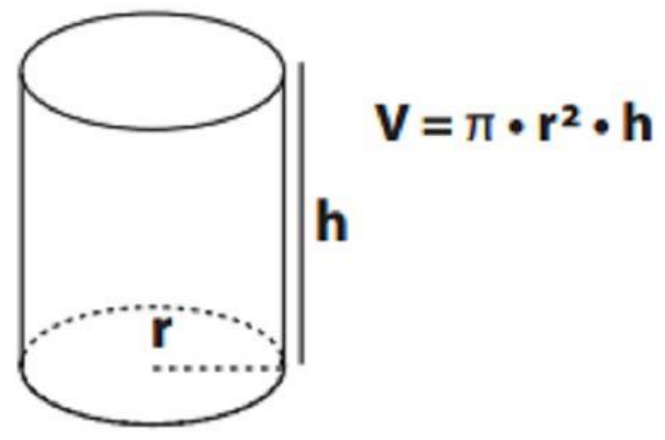

Figure 3. Cylinder formula. 


\section{Results}

Six hearts of the equine species were analyzed, 50\% (3) male and 50\% (3) females. As for race $33.3 \%$ (2) were Quarter Mile, 33.3\% (2) were Manga Larga Machador and 16.6\% (1) was Manga Larga Paulista and $16.6 \%$ (1) was PSI. About athletic life, 50\% (3) were considered equine athletes (Table 1) and the average weight of the animals was $426.83 \mathrm{~kg}$, with the lowest weight being $295 \mathrm{~kg}$ and the highest 560.0 $\mathrm{kg}$.

Table 1. Distribution of the characteristics of the equine species, according to race, sex, athlete and weight, Veterinary Hospital of the University of Franca (Unifran), Franca-SP, 2019.

\begin{tabular}{lccc}
\hline \multirow{2}{*}{ Variables } & & \multicolumn{2}{c}{ Equine $(\mathrm{n}=6)$} \\
\cline { 3 - 4 } Sex & & $\mathrm{n}$ & $\%$ \\
& Male & 3 & 50,0 \\
\multirow{2}{*}{ Breed } & Female & 3 & 50,0 \\
& Quarto de Milha & 2 & 33,3 \\
& Mangalarga Machador & 2 & 33,3 \\
& Mangalarga Paulista & 1 & 16,6 \\
\multirow{2}{*}{ Being an Athlete } & PSI & 1 & 16,6 \\
\hline
\end{tabular}

Regarding the dimensions of the analyzed hearts, the mean weight of the ventricles was $2.71 \mathrm{~kg}$, with the lowest weight being $1.63 \mathrm{~kg}$ and the highest weight being $3.83 \mathrm{~kg}$; on the size of the base, an average of $22.28 \mathrm{~cm}$ was found, with the smallest base being $17.0 \mathrm{~cm}$ and the largest base 25; as for the axis, the mean found was $25.66 \mathrm{~cm}$, the smallest being $22.0 \mathrm{~cm}$ and the largest being 30, (Table 2). Regarding the number of slices, sample 1 was the one with the least amount, with 9 slices, sample 2 and 5 had the largest number of slices totaling 12 parts.

Table 2. Description of equine characteristics and ventricle dimensions

\begin{tabular}{lcccccccc}
\hline Sample & Breed & Sex & Athlete & Colection Date & Animal Weight & Axis & Base & Ventricle weight \\
\hline 1 & MM & FEMALE & Não & $08 / 06 / 2018$ & 340 & 22.5 & 21.0 & $1.9 \mathrm{~kg}$ \\
2 & QM & MALE & Sim & $21 / 11 / 2018$ & 546 & 28.5 & 25.0 & $3.8 \mathrm{~kg}$ \\
3 & PSI-A & FEMALE & Sim & $28 / 11 / 2018$ & 460 & 26.5 & 23.0 & $2.7 \mathrm{~kg}$ \\
4 & MP & MALE & Não & $05 / 04 / 2019$ & 295 & 22.0 & 17.0 & $1.6 \mathrm{~kg}$ \\
5 & QM & MALE & Sim & $10 / 06 / 2019$ & 560 & 30.0 & 24.7 & $3.8 \mathrm{~kg}$ \\
6 & MM & FEMALE & Não & $01 / 07 / 2019$ & 360 & 24.5 & 23.0 & $2.4 \mathrm{~kg}$ \\
\hline Mean & & & & & 426.83 & 25.6 & 22.3 & $2.7 \mathrm{~kg}$ \\
\hline
\end{tabular}

Legend: MM - Mangalarga Machador; QM - Quarto de Milha; PSI - Puro Sangue Inglês; MP - Mangalarga Paulista

As for the measurements in slices 1 and 2, it was possible to identify the absence of the right wall in all samples and an average volume of the left chamber of $2.6 \mathrm{~cm}^{3}$ and $3.52 \mathrm{~cm}^{3}$ (Table 3)

Table 3. Description of the ventricular dimensions in slices 1 and 2.

\begin{tabular}{|c|c|c|c|c|c|c|c|c|c|c|c|c|c|c|}
\hline $\mathrm{A}^{*}$ & 1.PE & 1.PD & 1.CE-L & 1.CE-V & 1.CE-M & $1-\mathrm{VOL}$ & 1.SEP & 2.PE & 2.PD & 2.CE-L & 2.CE-V & 2.CE-M & $2-\mathrm{VOL}$ & 2.SEP \\
\hline 1 & 0.8 & 0 & 1.2 & 0.9 & 1.0 & 1.7 & 2.1 & 0.8 & 0 & 1.9 & 1.4 & 1.6 & 4.2 & 1.7 \\
\hline 2 & 1.4 & 0 & 1.4 & 1.4 & 1.4 & 3.1 & 1.1 & 2.6 & 0 & 1.1 & 1.2 & 1.1 & 2.0 & 2.2 \\
\hline 3 & 1.4 & 0 & 0.8 & 0.6 & 0.7 & 0.7 & 1 & 2.4 & 0 & 0.9 & 0.9 & 0.9 & 1.2 & 2 \\
\hline 4 & 1.2 & 0 & 1.7 & 1.5 & 1.6 & 4.0 & 1 & 1.4 & 0 & 2.1 & 1.7 & 1.9 & 5.6 & 1.5 \\
\hline 5 & 1.9 & 0 & 1.1 & 0.9 & 1 & 1.5 & 1.7 & 2.2 & 0 & 2.1 & 1.3 & 1.7 & 4.5 & 2.4 \\
\hline 6 & 1.4 & 0 & 1.7 & 1.7 & 1.7 & 4.5 & 1.3 & 3 & 0 & 1.6 & 1.3 & 1.4 & 3.3 & 3.1 \\
\hline Mean & 1.3 & 0 & 1.31 & 1.16 & 1.2 & 2.6 & 1.3 & 2.1 & 0 & 1.6 & 1.3 & 1.4 & 3.5 & 2.1 \\
\hline Unid. & $\mathrm{cm}$ & $\mathrm{cm}$ & $\mathrm{cm}$ & $\mathrm{Cm}$ & $\mathrm{cm}$ & $\mathrm{Cm}^{3}$ & $\mathrm{~cm}$ & $\mathrm{~cm}$ & $\mathrm{~cm}$ & $\mathrm{Cm}$ & $\mathrm{cm}$ & $\mathrm{cm}$ & $\mathrm{Cm}^{3}$ & $\mathrm{~cm}$ \\
\hline
\end{tabular}

Legend: A* The sample; PE - left wall; PD - right wall; CE-L - Left longitudinal chamber; CE-V - Left chamber measured vertically; CE-M - Middle left chamber; VOL - volume; SEP - Ventricular septum.

Regarding the measurements of slices 3 and 4, it is possible to observe hypertrophy of the left wall, presence of the right wall and an increase in volume and ventricular septum, (Table 4). 
Table 4. Description of ventricular dimensions in slices 3 and 4.

\begin{tabular}{|c|c|c|c|c|c|c|c|c|c|c|c|c|c|c|}
\hline$\overline{\mathrm{A}^{*}}$ & 3.PE & 3.PD & 3.CE-L & 3.CE-V & 3.CE-M3 & $3-\mathrm{VOL}$ & 3.SEP & 4.PE & 4.PD & 4.CE-L & 4.CE-V & 4.CE-M & 4.VOL & 4.SEP \\
\hline 1 & 2.5 & 1.0 & 3.2 & 2.2 & 2.7 & 11.4 & 2.8 & 2.7 & 1.4 & 4.0 & 2.3 & 3.1 & 15.5 & 2.9 \\
\hline 2 & 3.1 & 1.2 & 1.8 & 1.1 & 1.4 & 4.5 & 2.1 & 4.6 & 0.9 & 1.7 & 1.4 & 1.5 & 3.7 & 3.1 \\
\hline 3 & 2.9 & 0 & 1.5 & 1.7 & 1.6 & 4.0 & 2.5 & 3.0 & 1.0 & 2.6 & 1.9 & 2.2 & 7.9 & 2.7 \\
\hline 4 & 2.6 & 0.7 & 1.9 & 2.7 & 2.3 & 8.3 & 1.7 & 2.5 & 1.1 & 2.5 & 2.6 & 2.5 & 10.2 & 2.4 \\
\hline 5 & 3.6 & 0.8 & 2.0 & 1.7 & 1.8 & 5.3 & 2.7 & 4.0 & 1.2 & 2.7 & 1.7 & 2.2 & 7.6 & 3 \\
\hline 6 & 3.5 & 1.0 & 2.0 & 1.8 & 1.9 & 5.6 & 2.1 & 4.2 & 1.6 & 3.0 & 2.4 & 2.7 & 11.4 & 2.9 \\
\hline Mean & 3.0 & 0.8 & 2.1 & 1.8 & 1.9 & 6.5 & 2.3 & 3.5 & 1.2 & 2.7 & 2.0 & 2.4 & 9.4 & 2.8 \\
\hline Unid. & $\mathrm{cm}$ & $\mathrm{cm}$ & $\mathrm{cm}$ & $\mathrm{Cm}$ & $\mathrm{Cm}$ & $\mathrm{Cm}^{3}$ & $\mathrm{~cm}$ & $\mathrm{~cm}$ & $\mathrm{~cm}$ & $\mathrm{~cm}$ & $\mathrm{~cm}$ & $\mathrm{Cm}$ & $\mathrm{Cm}^{3}$ & $\mathrm{~cm}$ \\
\hline
\end{tabular}

Legend: A* The sample; PE - left wall; PD - right wall; CE-L - Left longitudinal chamber; CE-V - Left chamber measured vertically; CE-M - Middle left chamber; VOL - volume; SEP - Ventricular septum.

There was an increase in the measures from slice 5 to slice 6 , with the exception of the left wall measure, which showed a decrease of $0.2 \mathrm{~cm}$ (Table 5).

Table 5. Description of ventricular dimensions in slices 5 and 6.

\begin{tabular}{|c|c|c|c|c|c|c|c|c|c|c|c|c|c|c|}
\hline$\overline{\mathrm{A}^{*}}$ & 5.PE & 5.PD & 5.CE-L & 5.CE-V & 5.CE-M & $5 . \mathrm{VOL}$ & 5.SEP & 6.PE & 6.PD & 6.CE-L & 6.CE-V & 6.CE-M & $6 . \mathrm{VOL}$ & 6.SEP \\
\hline 1 & 2,4 & 1,8 & 5,7 & 3,5 & 4,6 & 33,2 & 3,3 & 2,6 & 1,2 & 5,0 & 3,8 & 4,4 & 30,4 & 4,1 \\
\hline 2 & 4,2 & 1,9 & 2,7 & 2,7 & 2,7 & 11,4 & 3,5 & 3,8 & 2,5 & 3,7 & 4,2 & 3,9 & 24,5 & 4,2 \\
\hline 3 & 3,9 & 1,7 & 3,0 & 3,0 & 3,0 & 14,1 & 3,1 & 3,4 & 2,0 & 3,9 & 4,1 & 4,0 & 25,1 & 3,6 \\
\hline 4 & 4,2 & 1,7 & 3,0 & 3,4 & 3,2 & 16,1 & 2,7 & 3,2 & 2,1 & 3,7 & 3,9 & 3,8 & 22,7 & 2,8 \\
\hline 5 & 4,2 & 2,1 & 3,9 & 2,3 & 3,1 & 15,1 & 4,1 & 4,9 & 2,9 & 4,1 & 4,1 & 4,1 & 26,4 & 4,7 \\
\hline 6 & 4,1 & 2 & 4,6 & 4,6 & 4,6 & 33,2 & 2,9 & 3,4 & 2,2 & 4,9 & 6,2 & 5,5 & 48,3 & 3,7 \\
\hline Mean & 3,8 & 1,9 & 3,8 & 3,2 & 3,5 & 20,5 & 3,2 & 3,6 & 2,2 & 4,2 & 4,4 & 4,3 & 29,6 & 3,8 \\
\hline Unid & $\mathrm{cm}$ & $\mathrm{cm}$ & $\mathrm{cm}$ & $\mathrm{Cm}$ & $\mathrm{Cm}$ & $\mathrm{Cm}^{3}$ & $\mathrm{Cm}$ & $\mathrm{Cm}$ & $\mathrm{cm}$ & $\mathrm{cm}$ & $\mathrm{cm}$ & $\mathrm{cm}$ & $\mathrm{Cm}^{3}$ & $\mathrm{~cm}$ \\
\hline
\end{tabular}

Legend: A* The sample; PE - left wall; PD - right wall; CE-L - Left longitudinal chamber; CE-V - Left chamber measured vertically; CE-M - Middle left chamber; VOL - volume; SEP - Ventricular septum.

Considering the measurements of slices 7 and 8, it was possible to observe hypertrophy of the left and right walls, in addition to an increase in volume, $43.4 \mathrm{~cm}^{3}$ and $47 \mathrm{~cm}^{3}$ (Table 6), respectively.

Table 6. Description of ventricular dimensions in slices 7 and 8.

\begin{tabular}{|c|c|c|c|c|c|c|c|c|c|c|c|c|c|c|}
\hline$\overline{\mathrm{A}^{*}}$ & 7.PE & 7.PD & 7.CE-L & 7.CE-V & 7.CE-M & 7.VOL & 7.SEP & 8.PE & 8.PD & 8.CE-L & 8.CE-V & 8.CE-M & 8.VOL & 8.SEP \\
\hline 1 & 3.2 & 1.2 & 5.5 & 4.1 & 4.8 & 36.2 & 3.7 & 2.7 & 1.1 & 5.4 & 4.2 & 4.8 & 36.2 & 3.8 \\
\hline 2 & 3.5 & 3.1 & 4.5 & 5.5 & 5.0 & 39.2 & 4.5 & 3.8 & 3.4 & 4.9 & 5.3 & 5.1 & 40.8 & 5.0 \\
\hline 3 & 3.9 & 1.1 & 3.7 & 6.0 & 4.8 & 36.9 & 3.9 & 3.7 & 2.2 & 4.8 & 4.3 & 4.5 & 32.5 & 4.3 \\
\hline 4 & 3.6 & 2.4 & 4.5 & 3.4 & 3.9 & 24.5 & 3.4 & 2.9 & 2.1 & 4.5 & 3.2 & 4.3 & 29.7 & 3.6 \\
\hline 5 & 4.8 & 3.1 & 4.9 & 5.9 & 5.4 & 45.8 & 5.6 & 5.5 & 3.0 & 5.6 & 6.5 & 6.0 & 57.4 & 6.0 \\
\hline 6 & 2.2 & 2.5 & 6.8 & 7.3 & 7.0 & 78.0 & 4.0 & 3.7 & 2.5 & 8.2 & 6.9 & 7.5 & 89.5 & 4.5 \\
\hline Mean & 3.5 & 2.2 & 4.9 & 5.4 & 5.2 & 43.4 & 4.2 & 3.7 & 2.4 & 5.5 & 5.1 & 5.4 & 47.7 & 4.5 \\
\hline Unid. & $\mathrm{cm}$ & $\mathrm{cm}$ & $\mathrm{cm}$ & $\mathrm{cm}$ & $\mathrm{cm}$ & $\mathrm{Cm}^{3}$ & $\mathrm{~cm}$ & $\mathrm{Cm}$ & $\mathrm{cm}$ & $\mathrm{cm}$ & $\mathrm{cm}$ & $\mathrm{cm}$ & $\mathrm{Cm}^{3}$ & $\mathrm{~cm}$ \\
\hline
\end{tabular}

Legend: $A^{*}$ The sample; PE - left wall; PD - right wall; CE-L - Left longitudinal chamber; CE-V - Left chamber measured vertically; CE-M - Middle left chamber; VOL - volume; SEP - Ventricular septum.

When measuring the measures of slices 9 and 10, a slight difference in size between the left and right walls was noticed, since the volume showed a significant increase of $55.7 \mathrm{~cm}^{3}$ and $70.8 \mathrm{~cm}^{3}$, Table 7 .

Table 7. Description of ventricular dimensions in slices 9 and 10.

\begin{tabular}{|c|c|c|c|c|c|c|c|c|c|c|c|c|c|c|}
\hline $\mathrm{A}^{*}$ & 9.PE & 9.PD & 9.CE-L & $9 . \mathrm{CE}-\mathrm{I}$ & 9.CE-M & I 9.VOL & 9.SEP & 10.PE & 10.PD & 10.CE-1 & $0 . \mathrm{CE}-$ & V10.CE-M & M 10.VOL & 10.SEP \\
\hline 1 & 1.6 & 1.1 & 4.9 & 4.0 & 4.4 & 31.1 & 3.0 & - & - & - & - & - & - & - \\
\hline 2 & 4.5 & 3.0 & 4.4 & 4.3 & 4.3 & 29.7 & 5.6 & 4.1 & 2.3 & 4.7 & 5.0 & 4.8 & 36.9 & 6.5 \\
\hline 3 & 4.7 & 2.0 & 3.8 & 4.1 & 3.9 & 24.5 & 5.1 & 4.0 & 1.8 & 6.2 & 4.6 & 5.4 & 45.8 & 3.8 \\
\hline 4 & 3.7 & 1.6 & 4.7 & 5.3 & 5.0 & 39.2 & 3.9 & 2.7 & 1.9 & 7.5 & 5.9 & 6.7 & 70.5 & 2.0 \\
\hline 5 & 4.2 & 3.2 & 6.6 & 7.9 & 7.2 & 82.5 & 5.5 & 4.3 & 3.0 & 4.9 & 8.4 & 6.6 & 69.4 & 5.6 \\
\hline 6 & 2.7 & 1.9 & 9.0 & 9.0 & 9.0 & 127.2 & 3.9 & 2.7 & 2.3 & 8.7 & 9.6 & 9.1 & 131.4 & 2.6 \\
\hline Mean & 3.6 & 2.1 & 5.6 & 5.7 & 5.6 & 55.7 & 4.5 & 3.5 & 2.2 & 6.4 & 6.7 & 6.5 & 70.8 & 4.1 \\
\hline Unid. & $\mathrm{cm}$ & $\mathrm{cm}$ & $\mathrm{Cm}$ & $\mathrm{cm}$ & $\mathrm{cm}$ & $\mathrm{Cm}^{3}$ & $\mathrm{~cm}$ & $\mathrm{~cm}$ & $\mathrm{~cm}$ & $\mathrm{~cm}$ & $\mathrm{~cm}$ & $\mathrm{~cm}$ & $\mathrm{Cm}^{3}$ & $\mathrm{~cm}$ \\
\hline
\end{tabular}

Legend: $A^{*}$ The sample; PE - left wall; PD - right wall; CE-L - Left longitudinal chamber; CE-V - Left chamber measured vertically; CE-M - Middle left chamber; VOL - volume; SEP - Ventricular septum. 
In slice 11, there was a decrease in the left and right wall of the ventricles, maintaining the volume increase to $100.11 \mathrm{~cm}^{3}$ (Table 8) .

Table 8. Description of ventricular dimensions in slice 11.

\begin{tabular}{|c|c|c|c|c|c|c|c|}
\hline $\mathrm{A}^{*}$ & 11.PE & 11.PD & 11.CE-L & 11.CE-V & 11.CE-M & 11.VOL & 11.SEP \\
\hline 1 & - & - & - & - & - & - & - \\
\hline 2 & 4 & 2 & 7.3 & 6.7 & 7.0 & 76.9 & 4.3 \\
\hline 3 & 3.6 & 2.2 & 6.6 & 5.1 & 5.8 & 53.7 & 4.0 \\
\hline 4 & - & - & - & - & - & - & - \\
\hline 5 & 2.6 & 2.9 & 10.2 & 9.5 & 9.8 & 152.3 & 4.2 \\
\hline 6 & 2.9 & 1.2 & 10.2 & 7.1 & 8.6 & 117.5 & 4.1 \\
\hline Mean & 3.3 & 2.1 & 8.0 & 7.1 & 7.8 & 100.1 & 4.1 \\
\hline Unid. & $\mathrm{cm}$ & $\mathrm{Cm}$ & $\mathrm{Cm}$ & $\mathrm{cm}$ & & $\mathrm{Cm}^{3}$ & \\
\hline
\end{tabular}

Legend: A* The sample; PE - left wall; PD - right wall; CE-L - Left longitudinal chamber; CE-V - Left chamber measured vertically; CE-M - Middle left chamber; VOL - volume; SEP - Ventricular septum.

In slice 12, both in equine 2 and 5, as they are male, athletes and with greater weight, it was possible to identify a decrease in ventricular walls (left and right) and an increase in volume to $114.92 \mathrm{~cm}^{3}$ (Table 9).

Table 9. Description of ventricular dimensions in slice 12 .

\begin{tabular}{lcccccccc}
\hline A* & $12 . P E$ & $12 . \mathrm{PD}$ & $12 . \mathrm{CE}-\mathrm{L}$ & $12 . \mathrm{CE}-\mathrm{V}$ & $12 . \mathrm{CE}-\mathrm{M}$ & $12 . \mathrm{VOL}$ & 12. SEP & Vol. T \\
\hline 1 & - & - & - & - & - & - & - & 200.04 \\
2 & 3 & 2 & 8 & 7.6 & 7.8 & 95.51 & 5.3 & 368.51 \\
3 & - & - & - & - & - & - & - & 246.65 \\
4 & - & - & - & - & - & - & - & 230.82 \\
5 & 2.5 & 1.9 & 10.6 & 7.9 & 9.25 & 134.33 & 3.2 & 602.36 \\
6 & - & - & - & - & - & - & - & 650.1 \\
Mean & 2.75 & 1.95 & 9.3 & 7.75 & 8.525 & 114.92 & 4.25 & 383.08 \\
Unid. & $\mathrm{cm}$ & $\mathrm{cm}$ & $\mathrm{Cm}$ & $\mathrm{cm}$ & $\mathrm{cm}$ & $\mathrm{Cm}^{3}$ & $\mathrm{~cm}$ & $\mathrm{~cm}$ \\
\hline
\end{tabular}

Legend: $A^{*}$ The sample; PE - left wall; PD - right wall; CE-L - Left longitudinal chamber; CE-V - Left chamber measured vertically; CE-M - Middle left chamber; VOL - volume; SEP - Ventricular septum.

\section{Discussion}

The profile of the participating horses was diverse and did not show a predominance of sex, race or performance of physical activity. It is recognized that the sample size was restricted to perform tests of association between the variables, however the sample size made it possible to perform a detailed analysis of each sample.

It is known that the heart undergoes changes according to the presence, absence, and the type of modality and physical activity. There are studies describing that the heart weight represents $0.75 \%$ of the animal's body weight (Dyce et al., 2004). The study covered different breeds, being: Mangalarga Machador, Quarter Mile, Purebred English and Mangalarga Paulista. The heaviest ventricles were those of the Quarter Mile horses, which have greater resistance to physical activity and these animals performed physical activity and also had the highest body weight. According to Hinchcliff et al. (2008), the weight of the heart seems to be related to the body weight of the animal, which may be associated with cardiac hypertrophy. However, there are reports that after correlation analysis, the weight did not show a significant correlative difference. with no function variable. This finding may be related to the fact that the heavier animals may not necessarily represent the best cardiac performance, as is the case of the Puro Sangue Inglês group, which in the study were the heaviest animals, and presented a physical performance below expectations. (Bonomo et al., 2014; Hinchcliff et al., 2008).

There are studies that show that the Puro Sangue Inglês animals participate in running tests, there is a linear relationship between the heart weight of these animals and the cardiac output, and between the cardiac output and the oxygen consumption, allowing these animals to present larger and healthy hearts, reaching 400-500 L/min of cardiac output and an oxygen consumption of $240 \mathrm{ml} \mathrm{O} / \mathrm{kg} / \mathrm{min}$ (Evans \& Rose, 1988). In the Quarter Horse race, it has the largest component of strength activity, based on the training and tests that participate, and these did not have the highest values of wall thickness (Bonomo 
et al., 2014). In this study, equine 6 of the manga race wide, female and non-athlete showed greater left wall thickness from the apex to the fifth cut, which allows the hypothesis of the presence of systemic arterial hypertension to be raised, however, horses 2 and 5 (quarter-mile, male and athlete) ) presented greater thickness of left appearance from the fifth cut to the base. This may be related to the greater development of the cardiac papillary muscles in the athlete horse submitted to extreme exercise

Among the most frequent cardiac changes that are associated with physical training, it is possible to observe the concentric increase of the left ventricular musculature, increase of the left ventricle mass and thickening of its wall. These changes are known as the "athlete's heart" (Pelliccia \& Maron, 1997). According to Morganroth et al. (1975), two types of athlete's hearts can be found: one that is submitted to strength training and one that happens after resistance training. Athletes involved in sports activities with the presence of a high dynamic component, such as running, can often develop an increase in the left cardiac chamber, a proportional increase in the wall caused by an increase in volume load associated with high cardiac output, that is, a eccentric hypertrophy of the left ventricle; whereas athletes involved in isometric physical activity, there is a predominantly increase in the thickness of the ventricular wall without changing the size of the left ventricle, characterizing this process by a concentric hypertrophy.

Regarding the ventricular septum, greater thickness was observed in animals 2 and 5, it is important to note that both had an active athletic life. According to Bonomo et al. (2014) physical training that requires resistance and strength, allows the establishment of eccentric and concentric hypertrophy. In this case, he studied PSI and Quarter Mile animals, which showed a better response of cardiac function at rest. As for the interventricular septum, this structure has an important influence on the systolic and diastolic response of the left ventricle for all groups of animals studied, reflecting on the function variables of the left ventricular ejection fraction and the shortening fraction, which showed a high correlation, being directly influenced by the size of the interventricular septum, both in diastole and in systole.

Diastole and systole undergo changes according to the presence and / or modality of physical activity practiced, as well as they will influence the stroke volume (Laughlin, 1999). It should be noted that the systolic volume of a horse at rest is approximately 800 to $900 \mathrm{~mL}$, or $2-2.5 \mathrm{~mL} / \mathrm{kg}$ (Bayly et al., 1983). The stroke volume increases by $20-50 \%$ in the transition from rest to physical activity (Thomas \& Fregin, 1981).

In this study, the formula for calculating the cylindrical volume was adopted to measure the ventricular volume, as it is a heart after death. This fact did not allow us to distinguish ventricular changes in relation to the presence of passive and active systole and diastole. It is also important to consider that there was no prior information about the presence or absence of underlying disease in the animals participating in this study, and data collection was performed after death. For these reasons, it was not possible to perform different measures of contraction and relaxation, which made it impossible to measure stroke volume and, consequently, cardiac output.

\section{Final considerations}

The practice of physical activity in horses seems to be associated with myocardial hypertrophy and this fact can decrease the lumen, increase the axis and this allowed for greater cuts and analysis of the structures. The morphoquantitative and physiological changes in the animal present the need for the companion of the veterinarian throughout the training process, such monitoring will allow better performance of the animal during the practice of physical activity.

\section{References}

Bayly, W. M., Gabel, A. A., \& Barr, S. A. (1983). Cardiovascular effects of submaximal aerobic training on a treadmill in Standardbred horses, using a standardized exercise test. American Journal of Veterinary Research, 44(4), 544-553.

Bonomo, C., Michima, L. E. S., Miyashiro, P., \& Fernandes, W. R. (2014). Avaliação ecocardiográfica do desenvolvimento cardíaco de cavalos atletas: comparação entre atividades físicas distintas. Pesquisa Veterinária Brasileira, 34(9), 923-927. DOI: https://doi.org/10.1590/s0100$\underline{736 \times 2014000900019}$ 
Cunningham, J. (2011). Tratado de fisiologia veterinária. Guanabara Koogan.

Dumont, C. B. S., Leite, C. R., Moraes, J. M., Alves, R. O., Godoy, R. F., \& Lima, E. M. M. (2010). Parâmetros eletrocardiográficos de equinos Puro Sangue Árabe submetidos a exercício prolongado de enduro. Ciência Rural, 40(1), 1966-1973. DOI: https://doi.org/10.1590/s010384782010000900018

Dyce, K. M., Wensing, C. J. G., \& Sack, W. O. (2004). Tratado de anatomia veterinária. Elsevier Brasil.

Evans, D. L., \& Rose, R. J. (1988). Cardiovascular and respiratory responses in Thoroughbred horses during treadmill exercise. Journal of Experimental Biology, 134(1), 397-408.

Ferreira, A., Silva, F., \& Afonso, R. (1996). Jogos Olímpicos: Um século de glória. Quid Novi, 1(1), $120-180$.

Hinchcliff, K. W., Geor, R. J., \& Kaneps, A. J. (2008). Equine exercise philosophy: the science of exercise in the athletic horse. In Saunders Elsevier. Elsevier.

Laughlin, M. H. (1999). Cardiovascular response to exercise. Advances in Physiology Education, 277(6), 244-259. https://doi.org/10.1152/advances.1999.277.6.s244.

Leite, E. P., Bombonato, P. P., Silva, F. O. C., Benedicto, H. G., \& Santana, M. I. S. (2004). Morfometria do tecido conjuntivo do coração de equinos PSI. Brazilian Journal of Veterinary Research and Animal Science, 41(3), 162-168. DOI: https://doi.org/10.1590/S1413-95962004000300003

Lima, R. A. S. ., \& Cintra, A. G. (2016). Revisão do estudo do complexo do agronegócio do cavalo (MAPA (ed.)). MAPA.

Marr, C., \& Bowen, M. (2011). Cardiology of the Horse E-Book. Elsevier Health Sciences.

Martin Júnior, B. B., Reef, V. B., Parente, E. J., \& Sage, A. D. (2000). Causes of poor performance of horses during training, racing, or showing: 348 cases (1992-1996). Journal of the American Veterinary Medical Association, 216(4), 554-558. DOI: https://doi.org/10.2460/javma.2000.216.554

Mirian, M. (2008). Padronização de teste incremental de esforço máximo a campo para cavalos que pratiquem hipismo clássico. Universidade de São Paulo.

Morganroth, J., Maron, B. J., Henry, W. L., \& Epstein, S. E. (1975). Comparative left ventricular dimensions in trained athletes. Annals of Internal Medicine, 82(4), 521-524. DOI: https://doi.org/10.7326/0003-4819-82-4-521

Pelliccia, A., \& Maron, B. J. (1997). Outer limits of the athlete's heart, the effect of gender, and relevance to the differential diagnosis with primary cardiac diseases. Cardiology Clinics, 15(3), 381396. DOI: https://doi.org/10.1016/s0733-8651(05)70347-7

Pluim, B. M., Zwinderman, A. H., van der Laarse, A., \& van der Wall, E. E. (2000). The athlete's heart: a meta-analysis of cardiac structure and function. Circulation, 101(3), 336-344.

Santos, J. M. C. M. (2015). Economia do entretenimento: o processo de monopolização do primeiro empreendimento esportivo no Brasil (1850-1930). Economia e Desenvolvimento, 27(1), 202-222. DOI: https://doi.org/10.5902/1414650919167

Thomas, D. P., \& Fregin, G. F. (1981). Cardiorespiratory and metabolic responses to treadmill exercise in the horse. Journal of Applied Physiology, 50(4), 864-868. DOI: https://doi.org/10.1152/jappl.1981.50.4.864

Yonezawa, L. A., Machado, L. P., Silveira, V. F., Watanabe, M. J., Saito, M. E., Kitamura, S. S., \& Kohayagawa, A. (2009). Exame eletrocardiográfico em equinos da raça puro sangue árabe submetidos ao exercício em esteira de alta velocidade e à suplementação com vitamina $\mathrm{E}$. Archives of Veterinary Science, 14(3), 134-142. DOI: https://doi.org/10.5380/avs.v14i3.15839

Young, L. E., Rogers, K., \& Wood, J. L. N. (2005). Left ventricular size and systolic function in Thoroughbred racehorses and their relationships to race performance. Journal of Applied Physiology, 99(4), 1278-1285. DOI: https://doi.org/10.1152/japplphysiol.01319.2004

Article History:

Received: December 16, 2020.

Accepted: January 15, 2021.
License information: This is an open-access article distributed under the terms of the Creative Commons Attribution License 4.0, which permits unrestricted use, distribution, and reproduction in any medium, provided the original work is properly cited. 